THE BIRDS OF THE

NATIONAL ARBORETUM

By John W. Taylor, Jr.

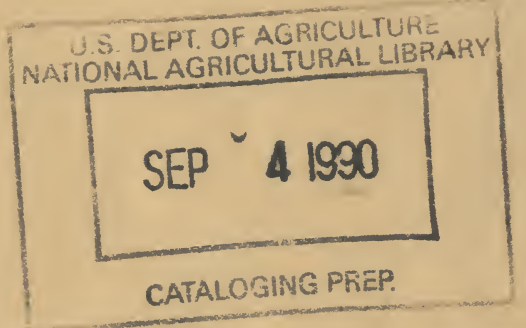

Washington, D. C.

July, 1947 


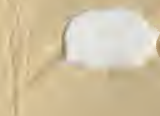

C

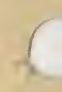




\section{THE BIRDS OF THE} NATIONAL ARBORETUM

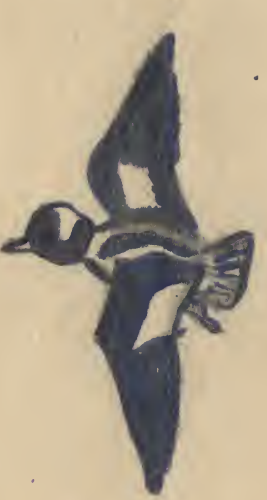

WASHINGTON, D.C.

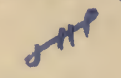

1947

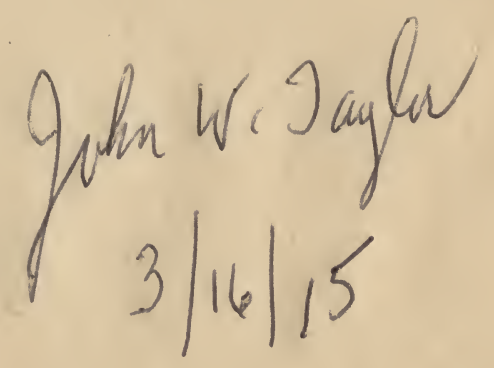

Jokn W. Taylor, Jr. -1947-JuLY 


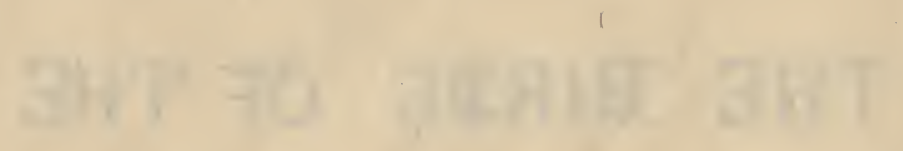

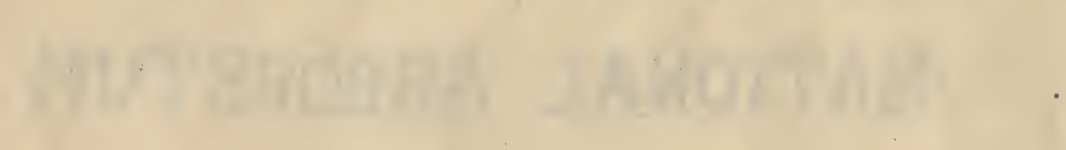




\section{INTRODUCTION \\ ros}

With its wide diversity of habitet, coupled with its rustic setting, the Netionzl Arboretum is an excellent place for birds. The dense decidiovs wood. lands, open fields, numerous conifers and liarge waterways make for variety not readily found elsewhere.

The woodlands have Searlet Tanagers. Hooded Warblers, Crested Flyeatchers and a great many others. In winter, roving flocks of Kinglets and Titmice find Food and shelter among them.

The more open spaces furnish room for the handsome Indigo Buntings, the whimsical Yellow-brested chats and the sweet-voiced Blvebirds. Ouail nest commonly in suitable locelities.

The National Arboretum is the only place within the District of Columbis where the Bald Eagle still nests. From the nest, a gigantic structure on a hill, near Bladensburg Road, one has a magnificent view of the city of Wrshington. The Wrohington Monument, the many downtown buildings and the Capitol of the United states, which long a go chose this great bird as the Aational emblem, are ll visible. Many hawks pay visits in Fall and winter, Finding a plentiful food supply in the many rabbits. sguirrels and field-mice which abound in the Arboretum. The georgeous, myjestic Ameriern Egret comes. in late summer and Great Blue Herons are with us the year-round.

The open river produces weterfowl not seen elsewhere near Wrohington. In March the Eastern Branch is often thronged with them.

In the following peges, is an attempt to tabulate the different species recorded in the Arboretum, and to give their status therein. Virtually all of those listed have actually been seen, with ill chance occurences in the Hypothetical or Probable List. The ares has been studidl for but very short while and the work is still far from complete. 


\section{Larraugontut \\ The.}

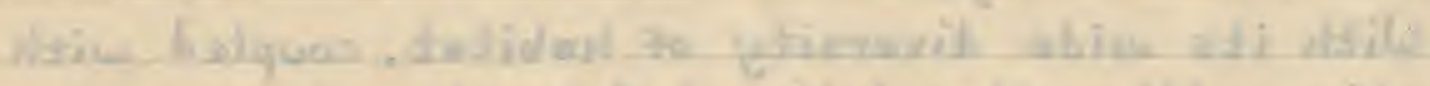

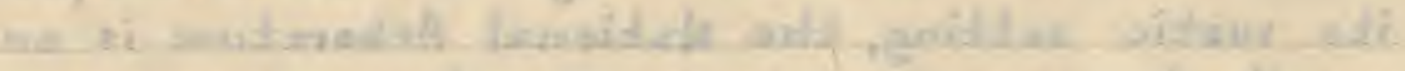

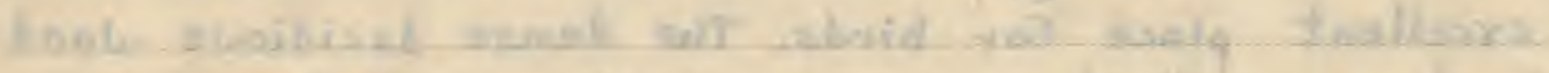

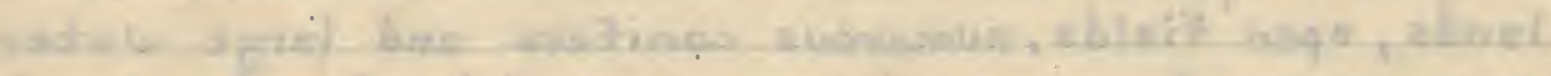

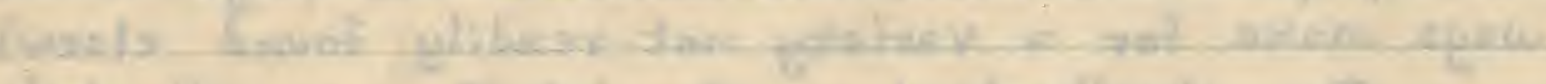

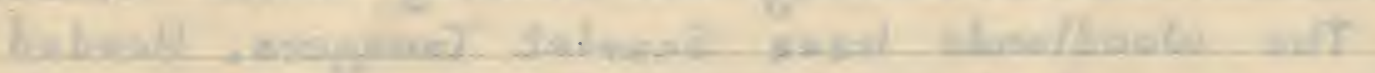

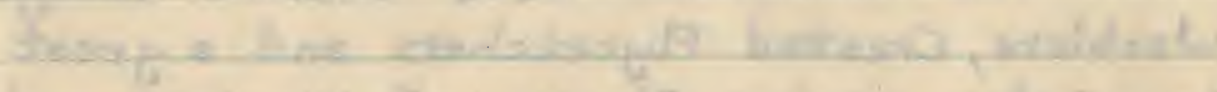

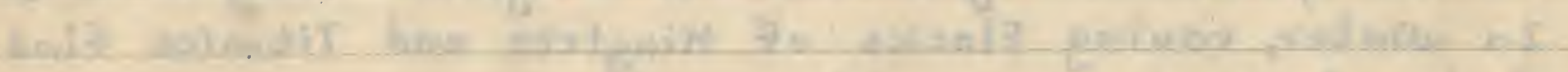

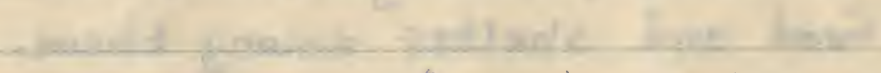

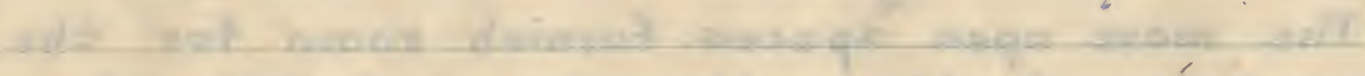

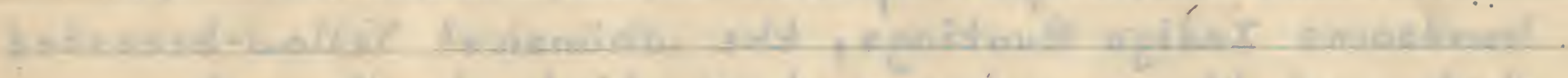

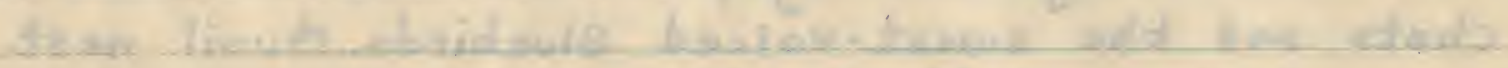

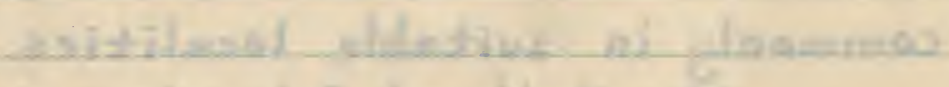

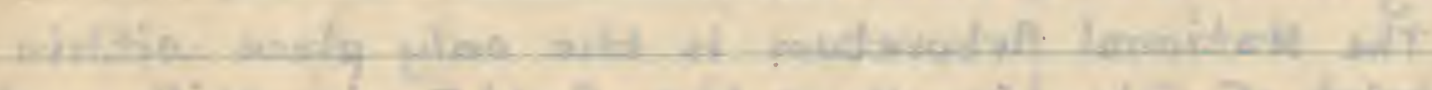

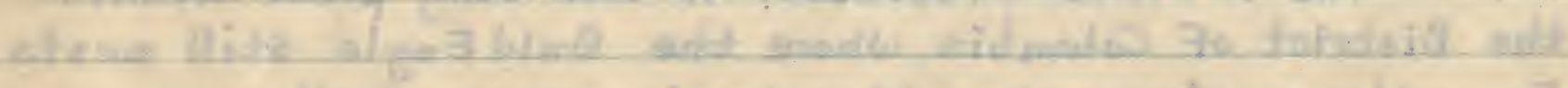

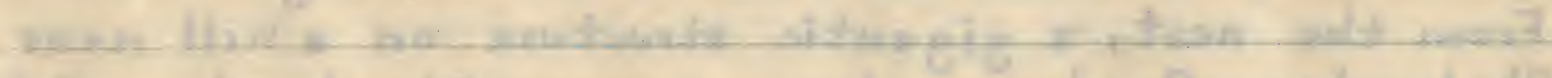

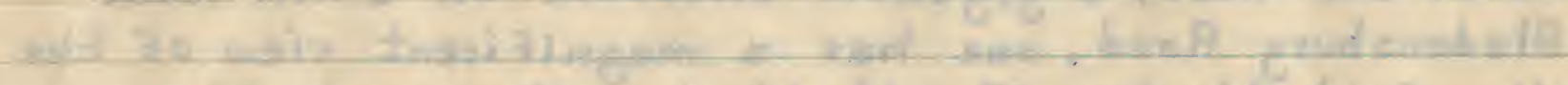

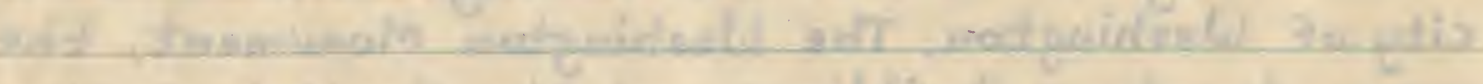

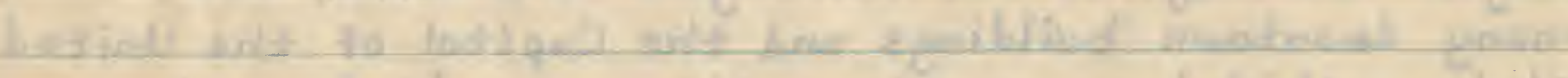

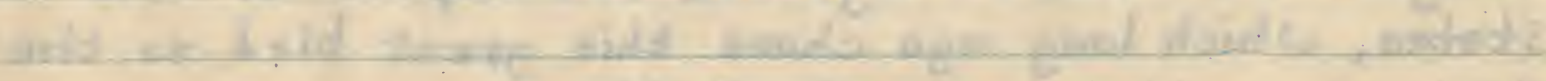

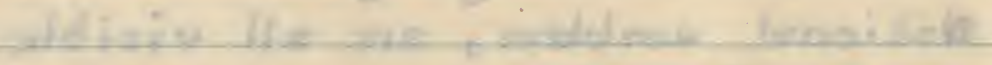

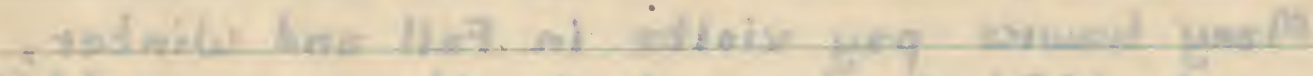

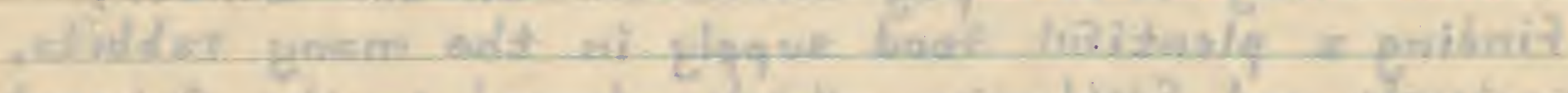

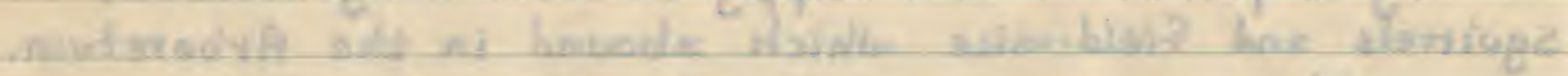

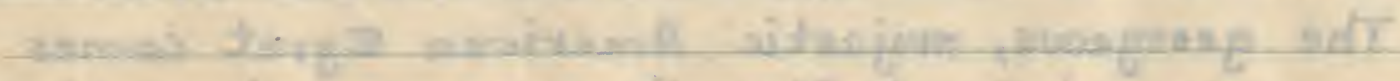

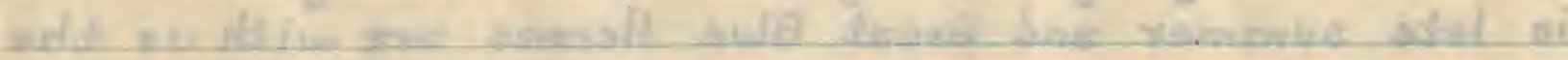

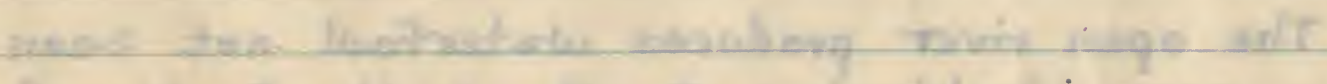

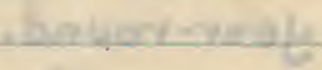

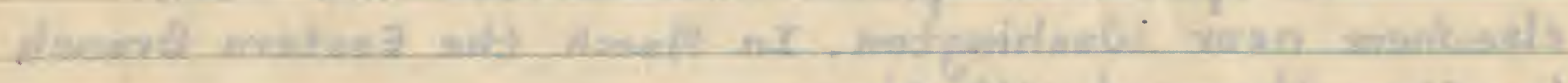

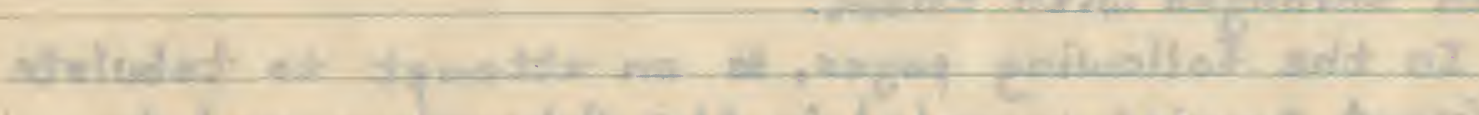

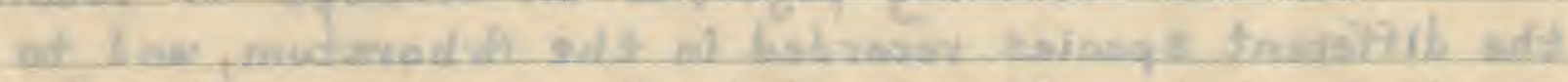

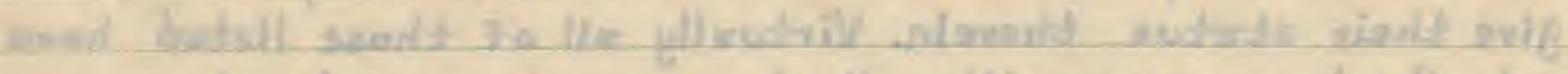

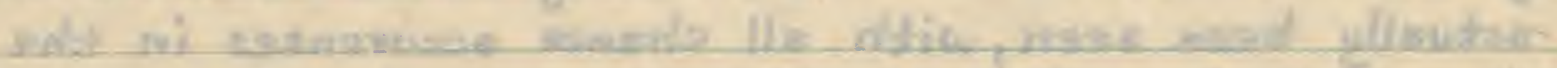

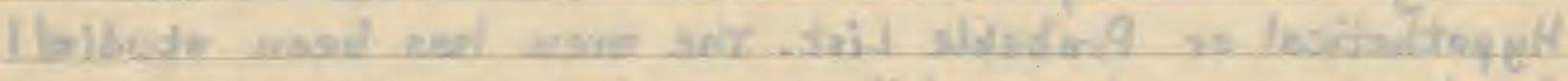

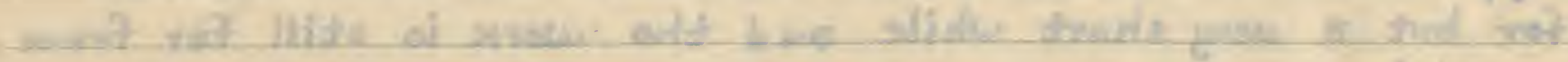


THE BIRDS OF THE NATIONAL

ARBORETUM

HORNED GREBE - Colymbes auritus

Uncommon migrant and rare winter visitor. This grebe prefers the larger open bodies of water, but oceasionally occurs inland in smaller lakes and rivers, especially in migration.

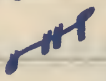

PIED-BILLED GREBE-Podijhinbus padiceps

Common migrant. The little "dab-chick" as it is often called, is freguently recorded in spring and foll on the Anacostia River and its tributaries located adjacent to the Arboretum

GREAT BLUE HERON-ardea herodias

$$
\text { Ht }
$$

Fairly common permanent resident. This big

"crane" often feeds in the smaller ponds located within the Arboretum. It is most common in September, becoming less so as colder wezther advences. Though it occurs commonly through-out the summer it is doubtful that it breeds in the near vicinity. as this species breeds chiefly in large, concentrated colonies. Those seen in summer are probably un-mated birds or non-breeders.

AMERICAN EGRET- Camerodius albus egretta

Common visitor in late summer. Occurs from July to October. This big "white crane" wanders somewhat after the breeding season and often large numbers may concentrote in this area.

\section{SNOWY EGRET-Egretta thula thula}

very rare late summer visitor. Has increased considerably due to protection, and in August and September its post-franding wandering may bring it to this area. 


\section{LITTLE BLUE HERON-Florida caerula caerula}

Almort all individuals of this species recorded herecbouts are in immature plumage. of more southerly breeding range, young birds tend to wander into the North. This species is fairly common in the Arboretum from middle July to the lest of September. its

GREEN HERON-Butorides virescens virescend

Summer resident, feeding commonly on the small Arboretum ponds, es well as on the adjecent Anacostia. Arrives in exrly April and usually leaves before the first week of Oetober.

BLACK-CROWNED NIGHT HERON- hyctuoraX nycteconas haacti

Common permanent resident, less abundant in midwinter. A small roost, consisting of $15-20$ birds is located across the river from the Arboretum and berons feed often In the small ponds.

\section{AMERICAN BITTERN-7Botaurus lentiginosus}

Rore migrant, stopping briefly in April and october, and Keeping well hidden in the marshes. This species is less common now than formerly.

LEAST BTTERN-Exobychus exilis exilé.

One pair usually is seen each summer in the mershes in the Kenilworth-Arboretum area.

MACLARD-anas platyskyeas platyphyneas.

occurs chiefly as a migrant, more common in fall, particularly in November, when small migrating flocks often stop in for a rest.

BLick DUCK-anas recbreis tristis

Resident from october to April in the marshy swamps. Rere, but reguler, and seldom remains for any length of time. The aren is too well-populated to suit ducks and they always soon clear aut. 


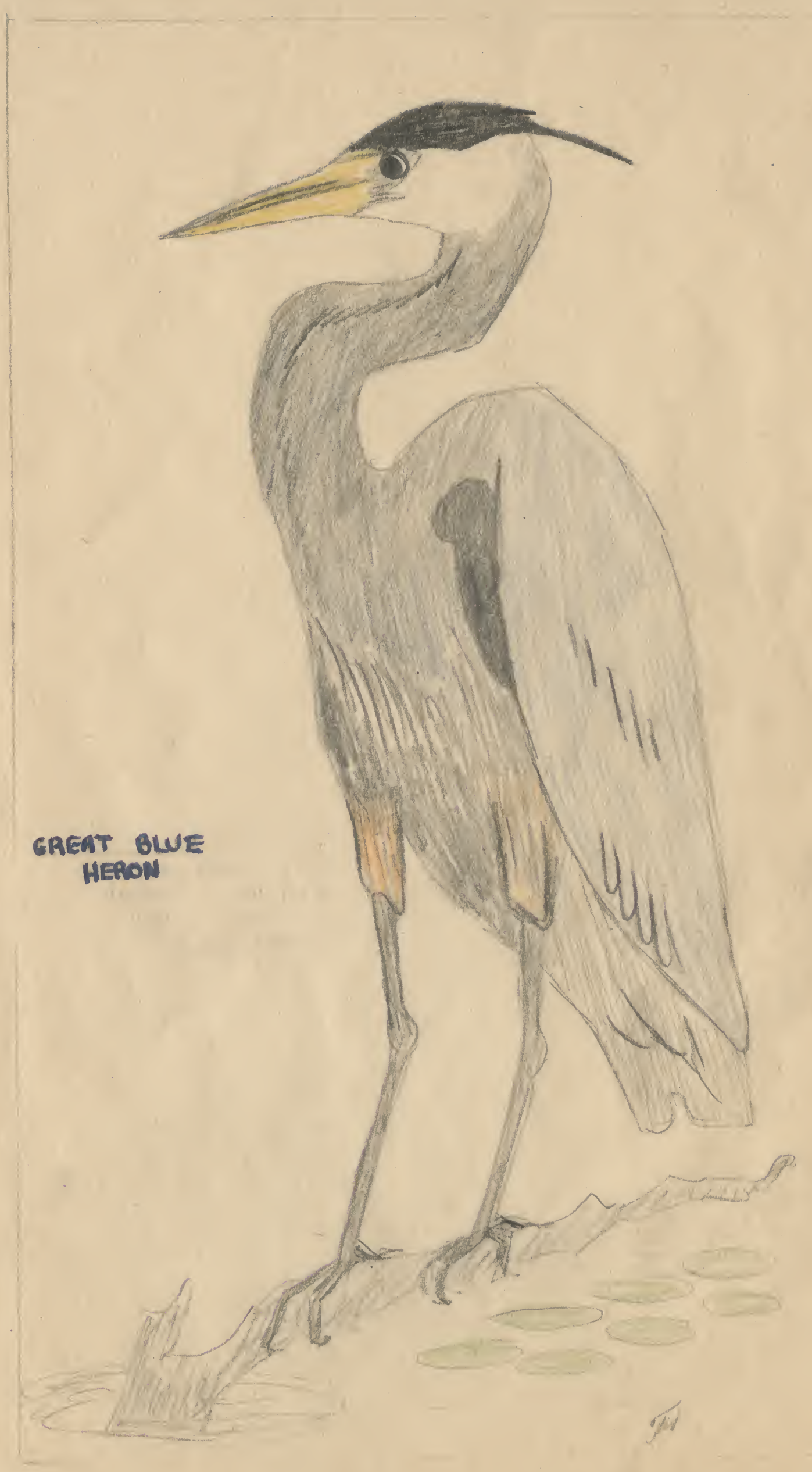



BALDPATE- mareca americana

Uncommon migrant, more freguently observed in Spring. on March 15, 1947, 7 Baldpates were seevi on the river, adjucent to the Arboretum. They rested and preened on the mud-flats and dabbled in the water at considerable length.

PINTAIL-Dafila acuta tyitghow

Rare winter visitor. This species winters commonly at Rozches Run Wildfowl Sanctuary in near-by Virginia, and-ocensionelly wander up the Eastern Brench this far.

GAEEN-WIMGED TEAL- Lettion caralinence

Rare migrent, even more so in spring. During migration, wedges of duek ore often seen high above the Anscostia. These Flocks consist chiefly of Black Ducks and Mullerds, but are often sprinkled with little pint-sized birds, no doubt this species.

BWE-WINGED TEAL- Overgcuedula deciors

Rare, but regulor in spring. Passes through this ares later than other ducks, occuring chiefly in late Merch or April. Almost unknown in Fall.

SHOVELLER- Spatula clypeata

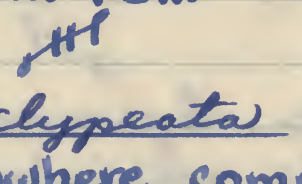

The "spoon-bill" is nowhere common in the East. In the Kenilworth-Arboretum area it is guite regular, but in amall numbers, inmigration, especially in spring.

\section{Woon Buck- aix sponsal}

$$
\text { rtP }
$$

May occur it any time through-out the year but is more likely in Spring migration. This, the goudiest of our wrter-fowl, is, unlike other duckes, spporently increasing in abundance.

REOHERD-hyocas americand

in lorge numbers in spring. A Flock was present throughout the entire month of Murch, 1947. 


\section{RING-NECKEO DUCK- hypaca collarid}

Though fer from common, this bird is probebly the most regular of the diving ducks. Unlike the other "boy ducks" it prefers smaller bodies of fresh water and finds this ever attrective in spring migration. Mry occur in Fell.

CANVASBACK- Reproca vahinerie

The lordly Canrasback is of kery irregulet occurence hereabouts. At present, it appeers in smell numbers in spring. but not in every year.

$$
\text { oth }
$$

ScAUP DUCK- Heproan marila

Uncommon migrant. Sometimes fairly large large flocks raft oce asionally on the Anacostia, especially in spring. On March 29-31, about 50 sezups, both lesser and greater, were seen on the river. (1947)

BUFFLEHEAD-charitonetta alheola

Irregular migrant. Was common during March, 1947, 1-4 indiriduals being present from the gth to the 31 st. The deinty little Bufflehead is a dicer, but likes the smaller bays and inlets rather than the sea-corst.

OLD-SAlAA-clongula hyemalis

This bird, which is associated in our minds with bleak wintry wastes, breeds along the artic coast and winters on the northern see-corists. There is, however, one record for the Arboretum ares: March 17-30, 1947, when-2-5 birds were seen by reputable observers on the adjacent Anecartia.

\section{AMERICAN MERGAMSER - mergens merganier amerianus}

Common resident from Norember to April. The big, ungamely "sheldrake" finds plenty of fish in the many lakes, ponds and river near the Arboretrum to his liking. 


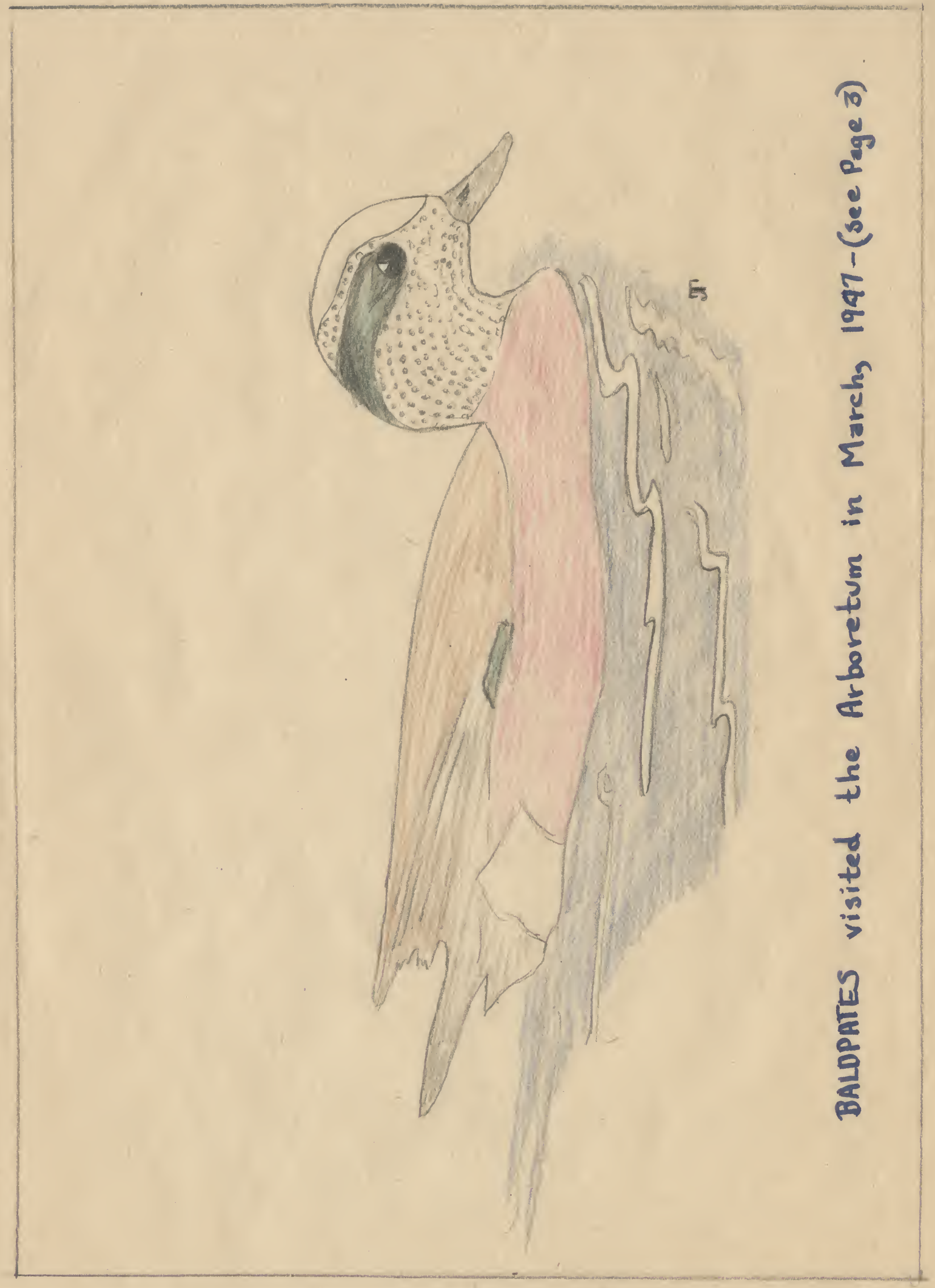



TURKEY VULTURE-cathartes aura septentriacali

Common visitor throughout the year, though it is - doubtful breeder. Possessed of marvelous powers awing, buzzards soar over the Arboretum, scanning the landscape for carrion, though the nest site may be quite distant.

BLACK VULTURE - Coragups atratew athatws

Rare visitor. May be expected in all Seasons, but more likely in winter.

SHARP-SHINUED HAWK- acajites velez velez

occurs from october to May. Never common, but the best month for it is November.

COOPER's HAWK-accipites coopers

Commonest of the accipiter hereabouts. Noted chiefly, but can be seen from october to May.

RED-TAILED HAwk -Buteo barealin barealin

Red-tails are common visitors throughout the winter and early spring, but none breed in the vicinity at present, though they probably have in fairly recent years.

ot

RED-SHOUWOERED-HAWK-Butes leveatus hiatus

status somewhat similar to hed-tailed, but less common. Mid-winter finds it in largest numbers.

BROAD-WINGEO HAWK- Buteo playteres playterus chiefly a migrant. Unlike other raptures, it migrates northward in pairs. April is its best month in the National Arboretum.

SPARROW HAWK- gallo spaveruis sparveries Common permanent resident, nesting in the outbuildings and prying rent by consuming large numbers of mice and injurious insects. At least 3 pairs nest within the grounds.

(5) 
BALD EACLE- Halietus leucacephahes leucoapkalue The Bald Eagle is the Arboretum's main ornithological attraction. A pair nests within stone's throw of Bledensburg Road, N.E., within the District of Columbia. The nest, which is approximately $5 \mathrm{ft}$. in diameter, is roughly 75 feet up in large Maple. The birds Frequent the nest area year round.

MARSH HAwK-Cinens hedonic

Fairly common migrant over the marshy Anvcostis. Seen most frequently in fall.

OSPREY-Pandion habited carolinenis.

Occurs from March to November but is usually not seen except in late summer and fall when individuals wander up From the Potomac.

HI

BOB-WHITE or SUAIL-Colenis virginians virginians Common permanent resident. The Nations Arboretum is one of relatively few places in the District where dual still nest.

SORA-Parzana Carobrea

Fall migrant, sometimes common in the vredjecent marshes.

FLORIDA GALUNULE- Sallinula chlropus cachenaind A bird of this species was recorded on May 25, 19476 in the nearby Kenilworth Aquatic Gardens.

Coot-gulici americana americana

Rather rave migrant on the nearby weter-weys. ot s

KILDEER- Oxyechue vaciferus vaciferw

Permanent resident. Common in summer, and large flocks Feed on the Anacostia mud-fluts throughout the winter.

(6) 


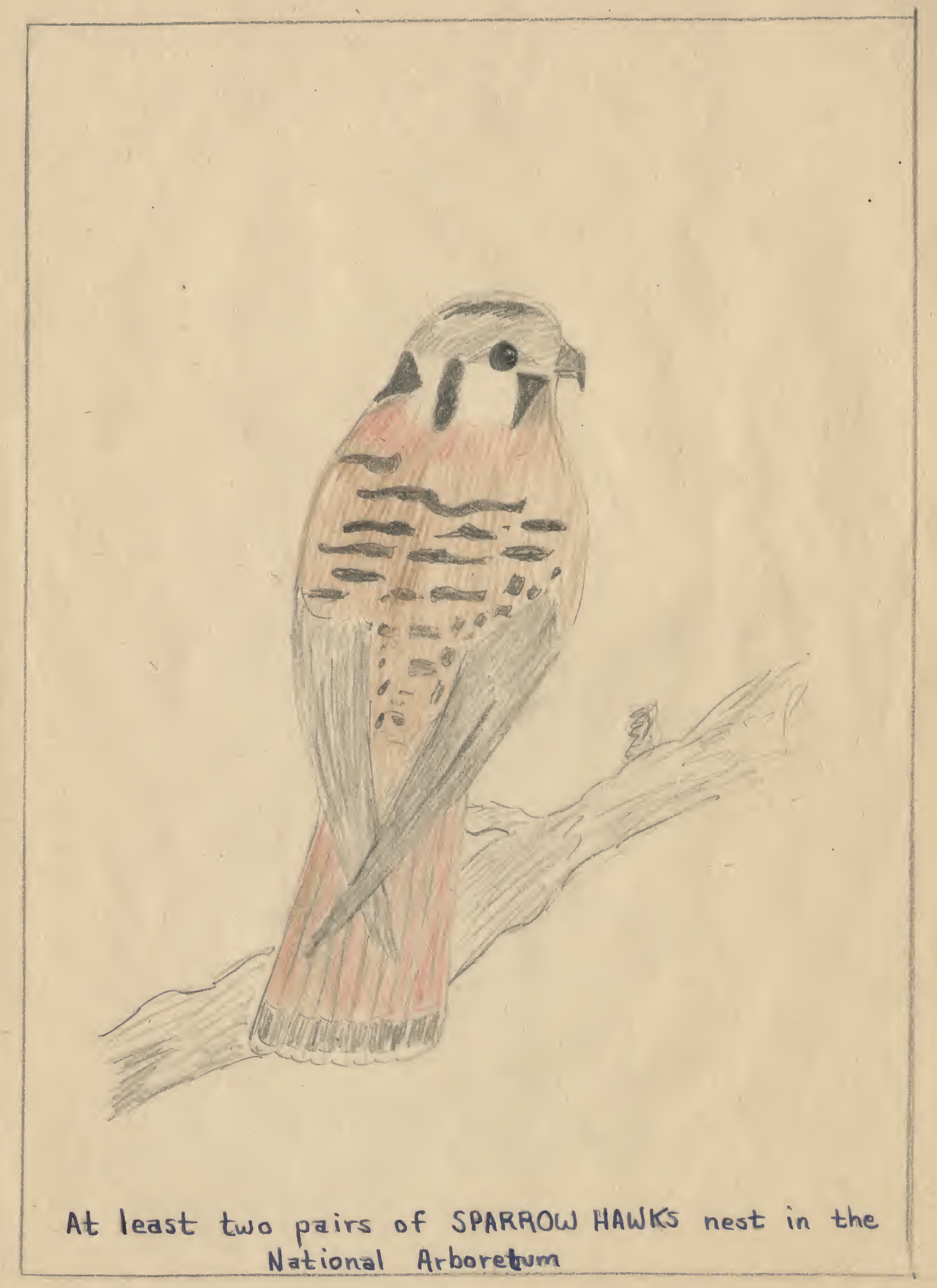





\section{Woopcock-philoheld navios}

Occurs chiefly as migrant, but individuals have been seen in July and August, which maje indicate breeding. Freguents boggy bottomland swamps, preferebly alder.

WILSON's SNIPE-capella delicatas

These birds are fast becoming rare on the Atlentic Cosst. The presence of two 2 individuals on Apraih 6,1945 is interesting if not spectaculor.

\section{SPOTTED SANDPIPER-actitis macularia}

Common in late summer and early fall, and Few in early spring. Probably doesn't breed too near the Arboretum

\section{SOLITARY SANDPIPER - greniga solituria solitarias}

Uncommon migrent, though guite regulor. Mid. April finds its numbers th their peak.

GREATER YELLW-LEGS-Iotanus melandeucus

Migront. duite rare beceuse the aree is too civilitied for such wild, wary bird.

$$
\text { int }
$$

HERRING GULL-Larus argentaties smitheoncinus

Abundant winter resident, feeding largely on the offal and dead fish greited by pollution in the Anacostic. They ere seldom scen before reslly cold whether sets in, and their numbers diminish rapidly as the temperature rises in spring. They are just about all gone by the weer of April.

\section{BING-BILLED GULL- Larus delawaremeis}

Somewhet less common than the Herring Gull, with which it associates. Arrives in lato November and leares in late March or early April. 
CommoN TERN-Sterna herindol heriendo

Irregular fall visitor. A flock of about 50 was observed on september 27, 1946, over the Eastern Branch, next to the Arboretum.

ot it

BLACK TERN-chlidoniad nigral surinancencis

A rare migrant, more likely in fall, but has been recorded in spring.

MOURNING DOVE-Zeniadura macroara carolicencis Permant resident. Suite common from March to November, but less abundant in mid-winter. Breeds in the National Arboretum.

ot h

YELLOW-BILLEO CUCKOO-COCagges americans

Fairly common summer resident in the open decidious woods, where its characteristic cackling is heard From May to september.

BLACK -BILLED CUCKOO-Cocyzus eryth-opthalmed Uncommon visitor, occurring chiefly as migrant, though it may breed rarely. The Black-bill is the less common of the two cuckoos hereabouts.

SCREECH OWL-otws asia asia

Permanent resident, varying in rbundrence. In some years o pair nests within the grounds, in others is almost totally absent.

BARRED OWL-Strix varia varia

This speer es is quite common in some nearby areas, but is an uncommon winter visitor in the Arboretum, as there no woodlands extensive enough to all breeding.

WHIP-POOR-WL-antrotomas vaceferes vaciferes Very rave in migration. This "goatsucker" loves the deep woods and occurs elsewhere only when forced to do so during migratory flights.

(8) 
NIGHTHAWK-chordeiles senior senior

Summer resident, though it is highly doubtful if they breed in the National Arboretum. Birds nesting on rooftops in the city often range far over the city.

ot h

CHIMUEY SWIFT- Chaetura pelagecal

Feeds commonly over the Arboretum from April to October, but does not breed there because of the lack of suitable nest sites.

at

RUBY-THROATED HUMMINGBIRD -archilochus colubrid

Fairly common summer resident from April to September.

BELTED KINGFISHER - megacengle aloyar alcyone

Permanent resident, more common in migration and rove in mid-winter. One pair usually nests near the Arboretum each year.

ot

FLICKER - Coleptes curated lutes

Permanent resident, somewhat less common in mid-winter. Large numbers of migrating flickers ere seen April and October.

H et

RED-BELLIED WOODPECKER-Centerus Carabin

Regarded as an uncommon winter visitor, though there ore catered summer records. Definitely has not bred in the National Arboretum in recent years.

RED-HEADED WOODPECKER- melaverpes erychrocephalus Permanent Resident, fluctuating in abundance. The Arboretum is well-suited to Aed-heeds, its high upland oaks, being well liked by this bird. Doesn't breed in every year.

YELLOW-BELHED SAPSUCKER- Phypapicas varies varies Uncommon visitor from october to May.

(9.). 
HAIRY WOODPECKER - Nrgobated willosud vellacus

Fairly common permanent resident some years two different pair breed within the grounds.

DOWWY WOODPECKER- Oryobated pubescent pobecend

Common permanent resident. 2-3 pair nest each year within the National Arboretum.

EASTERN KINGBIRD-gyraninew typandens

Common summer resident from April to september, when it becomes the most conspicious bird in the Arboretum. It is after seen pursuing the Bald Eagles, Sparrow Hawks and crows, driving them away from its nest site.

CRESTED FLYCATCHER- myiacher crinitud crinite

Common summer resident in the decidious woodlands, where it, like tho kingbird is gite a raucous fellow, tolerating nothing from any other bird, large or small.

PHOEBE- Layarnis phoebe

Resident from March to October. of very rare -ccurence in winter. Several nests are usually placed each year beneath the small bridges spanning the branch.

ACADIa AYCATCHER-Empidonat vereicens

Fairly common summer resident in low, moist woodlands. May to September

it

LEAST FLYCATCHER-Empidonex neivinee

Migrant. Not common. Would probably pass through unnoticed in May and september except for its distinctive call-note

WOOD PENEE- myjichanes vies

Common summer resident, arriving in early May and departing in september.

(10.) 


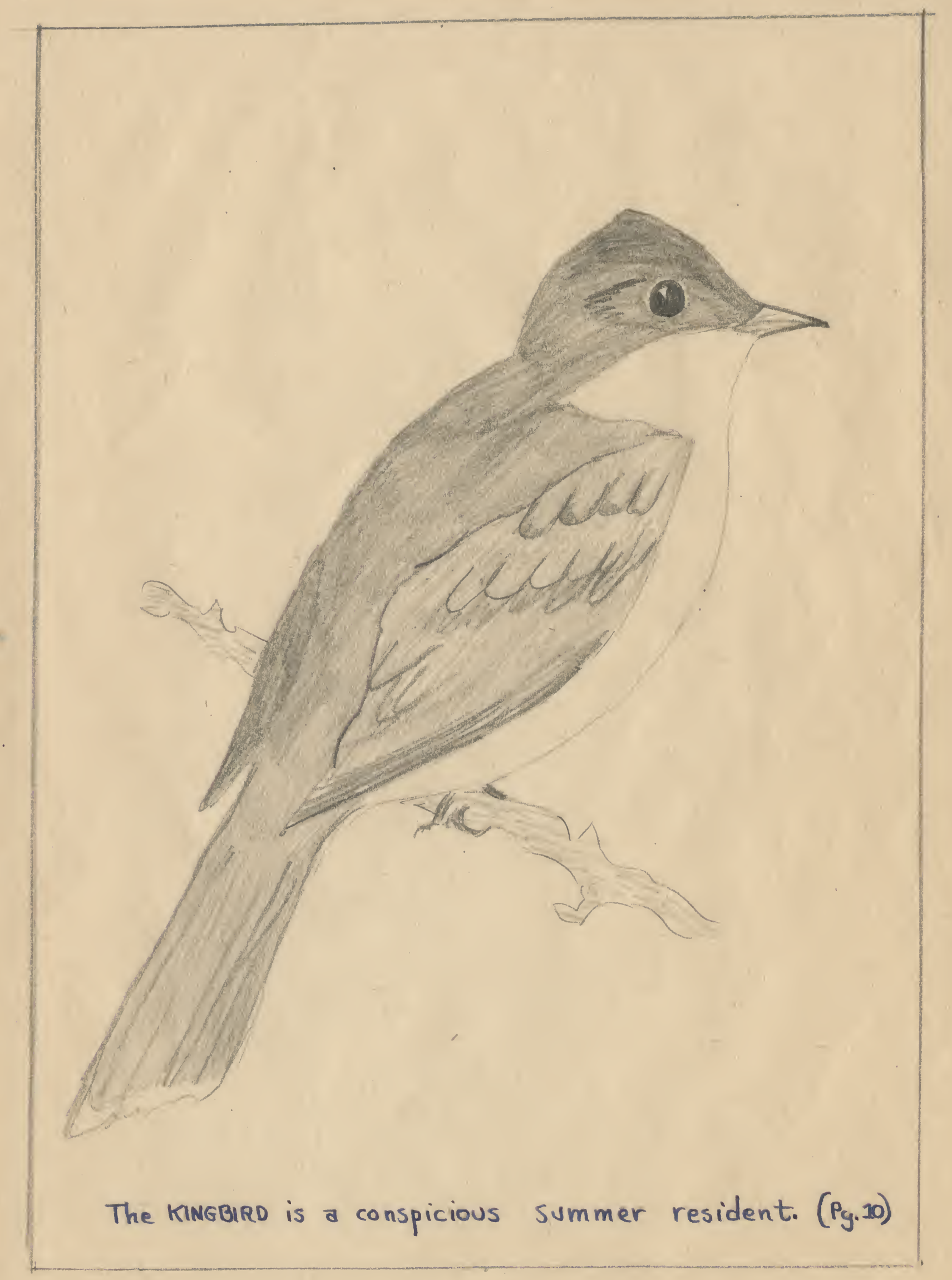



HORNEO LARK - otocanis alpestris praticola

Uncommon winter visitant, occuring sparingly in the open Fields. Move often seen flying over.

TREE SWALLOW- ridopeanel becolau

Migrant, occasionally in large numbers. Passes through in April and September.

BANK SWALLOW-Rejaria rejaria riparia

Summer resident, nesting locally in the mud-banks of the Eastern Branch or Anscostir River. Arrives in April; departs in september.

ROVGH-WINGED swAwOW-Stegidapterys rufecilli serrpainic occasionally seen over the river, at any time from April to october.

BARII SWALLOW-Herienda erythrogaster

Abundant summer resident. Seen constantly skimming over the fields and meadows, and nesting in the more open of the

ot t

BLWE JAY - Cyanocita cristate cristate

Common permanent resident. Gathers in small Flocks in foll and winter.

CRow-carwes hachyshercad hachyshypeas

abundant permanent resident, nesting and wintering in large numbers.

FISH CROW-Cowes assifregus

Permanent Resident, rare in winter and Fairly common in summer.

HI

CAROUNA CHICKADEE-Penthested carobninseria rolinensis

Common permanent resident. Nests early and young are on the wing by June.

(II) 
TUFTED TITMOUSE- Bacolophalus becilar

Common permanent resident, singing cheerfully the year round. More common in winter.

WHITE-BREASTED NUTHATCH-Sitta carolenenis corolinemis Permanent Resident. The Nations Arboretum is one of the few places within the District where this Wuthetch breeds.

NH

RED-BREASTEO NUTHATTH-Sitta canadenci

This species is lover of conifer forests, and stops by the Arboretum chiefly in migration, which may occur at any time from October thru May. Is more common in some years then in others.

BROWM CREEPER - cutches familiars americana

Uncommon winter visitant, from october to April.

HOUSE WREN-graglodytes aídon aida

Common summer resident, nesting in almost any situation. Occurs from April to september. it

WINTER WREN-Tannus hieinalis himali

Uncommon winter visitant. October to April

it

CARounA WREI- Ihyothared ludavicuanid.

Common permanent resident, somewhat less so in winter.

LONG-BILLEO MARSH WREN- gelmatodytes palwatis

Fairly common in the summer, frequenting the extensive cattail marshes bordering the Anacostia. occurs until october, and rarely, all winter.

ot it

MOCKINGBIRD-Imins palyglottad polyglotbos

Common permanent resident. Somewhat less so in winter.

(12) 
CATBIRD-Dumetella cardinenid

Common resident in the tangles and shrubbery From April to October.

BRow THRASHER- Soxastumeal rufume

The three mimics are ell regular visitors to the Arboretum. This one occurs from April to october, and breeds commonly.

RobiN-Iudus migeataried megiatories

Abundant summer resident an few individuals are present almost every winter.

WooD THRUSH-Hylocichla mustehia

Common summer resident from April to September, when its flute -like "E-O-LEE" rings out from the woodlands through-out.

At

HERMIT THRUSH-2tylocichla guttate guttate

Tolerably common migrant, and a few birds usually spend the Winter. Expect it from October to April.

H

OLVE-BACKED THRUSH- Itghocichla astaluta swainconi Fairly common migrant in May and october.

it

GRAY-CHEEKED THRUSH-Hffocichla minima alicia r

Status similar to the olire-becked, though perhaps it is less common.

VEERY - Ifglecichla funcescens funcenceses

Uncommon migrant. Earlier then the other Thrushes, arriving in the lIst week of April, wether permitting. Passes through practically unnoticed in October.

BLUEBIRD-silia salispailio

Permanent Resident. One pair usually nests within the grounds and Flocks of 5-20 are common in winter.

(13) 
BLUE-GAAY GNATCATCHER-Polioptila caerulea carmela of uncommon occurrence in July and August, after the breeding season, they tend to wander and are then recorded in the Arboretum. Hes not bred in recent years.

GOLPEN-CROWNE0 KUKGET-Regulus satrap satrap

Common winter visitant from october to April.

ot

RUBY-CROWNED KINGLT-Corthylio calendula calendula

Common migrant; rave in winter. Migrants ave seen March, April and October, November.

CEPAR WAXWING-Bombycilla cedorum.

Permanent Resident. The waxwing is a gregarious species and are seen lin largo flocks From september to May. It is y late neater, not beginning until July. There are records for summer, but es yet no positive evidence of breeding.

STARWWG-Sturnas volganis vilgaris

Abundant permanent resident at present, but has not always been. Was introduced into the United states from Europe in 1891, and was first hereabouts in 1912. Has increased very rapidly, as matt species tend to do when naturilized in : foreign country

WHITE-EYED VIREO- Vied gresins greisens

Common summer resident in the low, wet shrubbery where its greer "song" is heard, though the bird remains unseen.

YELLOW-THROATED VIREO-Virea flavife

Toleroby common summer resident in the open woodlands. April to september.

ont

(18) 
BLE-HEAOEO (SOLTARY) VIAEO-Vhio solitaries salitarmid.

Rather rave migrant, move often observed in spring than in Fall.

RED-EYED VIREO-Viea alivacens

Abundant summer resident. The woodlots ere often filled to capacitywith these birds.

BLACK AKD WHITE WARBLER- Mexictil. varia

Though this species is listed as a breeder in the Washington area, there has been no recent evidence of it doing so in the Wetiond Arboretum. Is, however, fairly common in migration during April and September.

its

WORM-EATING WARBLER- Helmitheros vermovions

The wooded hillsides and ravines of the Arboretum

should be especially attractive to this species, but, strangely enough, it is an uncommon migrant and rare summer resident.

GOLOELININGEO WAABLER-Vermivara cheproptera

Rare migrant. May and August, September.

BLVE-WIWGED WARBWER-Vermuiala pines

Status similar to adhering's.

PARULA WARBLER - comprgetypis

Abundant migrant and, when conditions are favorable, and uncommon breeder. April to September.

YELHOW WARBLER- Oendraica acativa aestival Common summer resident, Frequenting willows fringing the ponds and the river. Late April to september pot

MAGNOWA WARBLER-Aendsocia memorial

Common migrant in May. Somewhat less so in the less pronounced fall migration in August and september.

(15) 
BLACK-THROATED BLUE WARBLER-Aendrocia Caernlencenc.

Common migrant in May and september. Is seldom. seen, but betrays lis presenter by its ling, dreamy song.

BLACK-THROATED GREEN WARBLER-Aeadrocica veins verein s Migrant. Common in May and some what less so in Fall.

MYRTLE WARBLER-OSendroies coronata

Abundant migrant in April and october. Also a fairly common winter visitor.

BLACKBURNIAN WARBLER- Dendrocia fence

Rather rare migrant in May and September.

CHESTUUT-SIDED WARBLER-Dendrocia pencylvanica common migrant in May. Infrequent in fall migration.

BAY-BREASTED WARBLER- Mendrocia casterea

Uncommon migrant. More often recorded in fall.

oft

BLACK-POLL WARBLER-Nendracia striate

Abundant Migrant. May and August, September. Last to leave in spring and one of the first to arrive in fall.

PME WARBLER-Nendracia penis penis

Migrant; not common. Occurs in mixed woods in migration.

PARIRE WARBLER-Audracia deciolas decicalas

Aether rare summer resident within the

Arboretum, though it is often common in the neer-by countryside.

PALM WARBLER-Nendroica palmainen palmaruen

Common migrant. One of the hardiest of warblers, it arrives in late $M$ arch and, in Fall, often stays well into october.

(16.) 
WATER-THRUSH- Reminds motacilea

occurs chiefly 28 a migrant in April and September, but may breed in suitable localities.

rit

KENTUCKY WARBLER-aporarcid famous

Summer resident, varying in abundance. In some years common, in others quite rare.

its

YEUOW-THROAT Keochypid tricked tichas

common summer resident. Prefers the wet places, but high weeds, even in dry upland fields, are a Favorite habitat. April to September.

YELLOW-BREASTEO CHAT- Atria rind revised This weird-zeting species is a tolerably common summer resident. It is quite secretive in habits anditi"crazy" song is often the only clue to its presence.

HOODED WARBLER-Zlilsonia citric

Common summer resident from May to September.

Its song is quite distinctive, and may rendered verbally as "wee, wetter, WEETEO:"

OVENBIRD-Soinen aucocapilus

Abundant summer resident in decidious woodlands, but always Keeping close to the ground.

CANAPA WARBLER WILSONia canadenia

Common migrant in May and September.

AMERICAN REDSTART-Letaphaga ruticiela

Common migrant in Nay and September, and an uncommon breeder. This species is abundant and well distributed on the North American continent and it is quite puzzling why it does not breed in larger numbers.

(17.) 
ENGLISH SPARROW-Pascer domesticid domenticus Common permanent resident around the outhouses and sheds. Not native to this continent, it was first introduced in 1871, and proceeded to increase very rapidly. In recent years, however, it has apparently decreased slightly.

BOBOLINK-Oolichong arygivarus

Tolerably common migrant. Frequents the grassy meadows in April and May and the reedy marshes in Fall migration, where they feed on wild rice.

EASTERN MEADOWLARK- Sturnelea magma magma common resident from March to November, and uncommon visitor in mid-winter.

RED-WIWEED BLACKBIRD-agelavid phoenceins $F$.

common permanent resident in the cattail marshes. More abundant in winter, when large flocks congregate in the swamps.

ORCHARD ORIOLE- Rcterna

common migrant and tolerably common breeder. April to september.

of

BALTIMOAE ORIOLE- ecterud galbula

Uncommon migrant and rare breeder. May to September.

RUSTY BLACKBIRD-Eypageed caroline

Uncommon migrant in the wooded swamps. Match and october, November.

of

GRACKLE-Oviscalus quicula quicula

Common resident From March to October, Less. common than formerly.

(18) 
COWBIRD- molathrus aten aten

May occur at any time throughout the yer, but is very rare in mid-winter, and uncommon in summer. Common in March, April, May, September and october.

CARDINAL-Richmondena culdinali carderiali

Abundant permanent resident. Cardinals are said to be non-migratory and remain all their lives near their birthplace unless driven away by food shortages or other natural causes.

SCARLET TANAGER-Pianga erychromelas

Abundant migrant and common summer resident, Frequently the upper fiolage of the decidious woods. Arrives in late April and departs, in September. HI

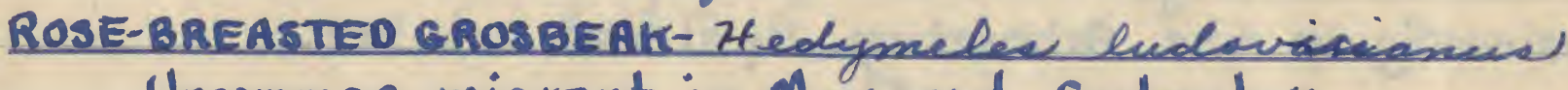
Uncommon migrant in May and September.

INDICO BUNTING - Passerine cyme

Abundant summer resident From May to September. A tireless and persistantsongster, this species sings all dey long and all summer.

Nth

PURPLE FINCH-Carpodaces p. penperens

Fairly common visitor from october to April.

PINE SISkIl-spexius pries penis

Irregular winter visitant, in some years common, in others almost unknown.

GolpFincH-Spenim trifid twisted

Common permanent resident, associating chiefly in small groups, except during the nesting season, which does not begin until July.

(19.) 
REO-EYED TOWHEE-Pepila erychrophthalmad e.

classed as permanent resident in that few individuals remain in winter. It is far more common from March, when new migrants arrive, until November, when they depart.

SAVANWAH SPARROW-Passerahlus sandwechescid savarexia Uncommon migrant in old, grown-up fields. March and october.

GRASSHOPPER SPARROW-ammadhamus savannarum austral

Summer resident; not uncommon. Prefers high, weed-grown Fields. Arrives early in spring, about the and week of April and leaves in october.

or

VESPER SPARROW-Procetes graseinews graminens

Common in migration, and perhaps a few breed occasionally in the Arboretum. April the october.

SLATE-COLORED JUNCO-gumeo hymali hymali

Abundant winter visitant, arriving in october and leaving in April.

TREE SPARROW- Ppizelew arbareaprharea

This hardy species usually doesn't reach this far south until late November or December and leaves very early in March.

CHIPPING SPARROW-Spizcelas passerexia passerines

Common summer resident, waking its nest around the houses. Arrives in April and stays until october.

FIELD SPARROW-Apijella pill purilla

Permanent resident, less common in winter. In summer, slow y whistled song is one of the most characteristic of bird songs in the Nations Arboretum.

(a) 
WHITE-CROWNED SPARROW-2onotrichia hencaphyps $l$.

Rare migrant in April, May and october.

WHITE-THROATEO SPARROW-2onatichea albicallis

Abundant migrant and common winter resident.

Large numbers pass through in october and again in April.

FOX SPARRow-Passerela ilia ss iliac

Common migrant, and a Few winter in sheltered localities. Migrants are seen in March and October, November.

SWAMP SPARRON-Melogpezas geargeaina

Migrant. Sometimes common in October and March. Keeps to the damp areas near the Anacostia.

SOW G SPARROW-Inelospiga melodia melodia

Common permanent resident, and abundant in migration.

-

HYPOTHETICAL OF PROBABLE

LIST

The following species are doubtless of rare occurrence in the National Arboretum, but have never actually been recorded, and are therefore transferred to i Hypothetical List:

Common Loon

Canada Goose

Gadwall

Hooded Merganser

Bonapartés Gull

Alder Flycatcher

Purple Martin

short-billed Marsh Wren

American Pipit

Loggerhead shrike

Warbling Vireo

Prothonotary Warbler
Tennessee Warbler

Nashville Warbler

Cape Mag Warbler

N. Water-thruah

Wilson's Warbler

Blue Grosbeak

Evening, Grosbeak

Henslowe's Sparrow

Lincoln's Sparrow

(21) 


\section{CONCLUSIONS}

A total of 162 species, plus 21 probables, occur in period of 12 months within the confines of the Nutional Arboretum, encompessing an ares of 3000-odd acres. of these, 78 species moy be expeeted to breed.

THE END

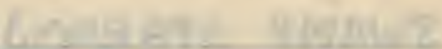

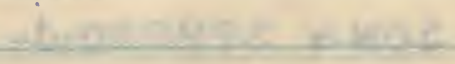

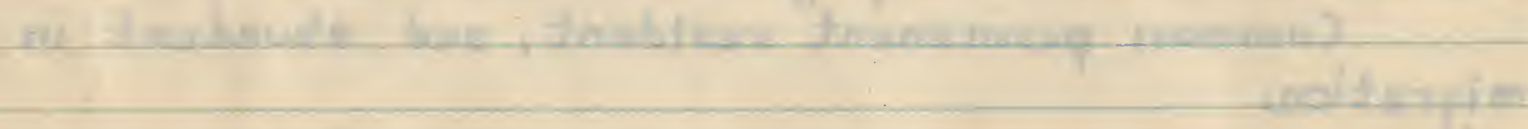

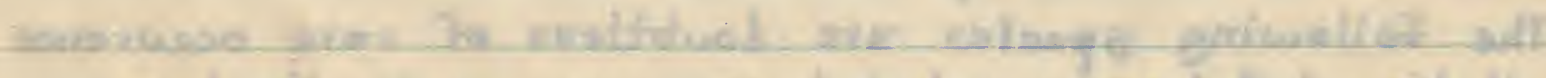





\& 